\title{
Unscheduled DNA synthesis in xeroderma pigmentosum cells after microinjection of yeast photoreactivating enzyme
}

\author{
J.C.M. Zwetsloot ${ }^{\text {a }}$, J.H.J. Hoeymakers ${ }^{\text {a.b }}$, W. Vermeulen ${ }^{\text {a }}$, A.P.M. Eker ${ }^{\text {c }}$ \\ and D. Bootsma ${ }^{\text {a }}$ \\ "Department of Cell Biology and Genetics, Erasmus University Rotterdam, P.O. Box 1738, 3000 DR Rotterdam, \\ " Medical Biological Laboratory, TNO, P.O. Box 45, Rijswijk and "Biochemical and Biophysical Laboratory, Delft University of \\ Technology, Julianalaan 67, Delft (The Netherlands) \\ (Received 9 April 1985) \\ (Revision received 1 June 1985) \\ (Accepted 22 August 1985)
}

\section{Summary}

Photoreactivating enzyme (PRE) from yeast causes a light-dependent reduction of UV-induced unscheduled DNA synthesis (UDS) when injected into the cytoplasm of repair-proficient human fibroblasts (Zwetsloot et al., 1985). This result indicates that the exogenous PRE monomerizes UV-induced dimers in these cells competing with the endogenous excision repair. In this paper we present the results of the injection of yeast PRE on (residual) UDS in fibroblasts from different excision-deficient XP-strains representing complementation groups A, C, D, E, F, H and I (all displaying more than 10\% of the UDS of wild-type cells) and in fibroblasts from two excision-proficient XP-variant strains.

In fibroblasts belonging to complementation groups $\mathrm{C}, \mathrm{F}$ and $\mathrm{I}$ and in fibroblasts from the XP-variant strains UDS was significantly reduced, indicating that pyrimidine dimers in these cells are accessible to and can be monomerized by the injected yeast PRE. The UDS reduction in the XP-variant strains is comparable with the effect in wild-type cells. In cells from complementation groups $\mathrm{C}, \mathrm{F}$ and $\mathrm{I}$ the reduction is less than in wild-type and XP-variant cells. Fibroblasts belonging to groups $\mathrm{A}, \mathrm{D}, \mathrm{E}$ and $\mathrm{H}$ did not show any reduction in UDS level after PRE injection and illumination with photoreactivating light. These results give evidence that the genetic repair defect in some XP-strains is probably due to an altered accessibility of the UV-damaged sites.

Xeroderma pigmentosum (XP) is an autosomal recessive disease with an extensive heterogeneity in clinical and biochemical features (Lehmann and Karran, 1981; Kraemer, 1983). Affected individuals develop an atrophic skin with pigmentation abnormalities and malignant growth in areas exposed to sunlight (including basal carcinomas, squamous carcinomas and malignant melanomas). A number of patients have neurological disorders and are mentally retarded. It was demonstrated that the removal of UV-induced DNA damage as measured by unscheduled DNA synthesis (UDS) is (partially) deficient in XP-fibroblasts (Cleaver, 1968) belonging to 9 different complementation groups, XP-A through I (de Weerd-Kastelein et al., 1972; Fischer et al., 1985). In XP-variants, the excision-repair capacity seems normal but abnormalities are registered in the process of postreplication repair (Lehmann et al., 1975).

In addition to excision-repair and postrepli- 
cation-repair photoreactivation of pyrimidine dimers was demonstrated in many organisms, i.e. in prokaryotes, lower eukaryotes, protozoa, crustacea, insects, echinodermata, fishes, amphibians, reptiles, birds and marsupials as well as lower and higher plants (Cook, 1970; Setlow, 1972; Rupert, 1975; Eker, 1983). The presence of PRE in rodents and primates could not be demonstrated unequivocally (Sutherland et al., 1974a,b, 1982; Mortelmans et al., 1977).

In a previous paper we have demonstrated that microinjection of purified PRE from yeast ( $\mathrm{Sac}$ charomyces cerevisiae) reduces UV-induced UDS in wild-type human fibroblasts (Zwetsloot et al., 1985 ) thus indicating that dimers in the chromatin of these cells are monomerized by the exogenous PRE. In this paper the effect of microinjection of PRE from yeast on the residual UDS of fibroblasts belonging to different XP-complementation groups was presented. The injected PRE significantly reduced (residual) UDS in cells from complementation groups C, F, I and in XP-variant but not in cells from the groups $\mathrm{A}, \mathrm{D}, \mathrm{E}$ and $\mathrm{H}$.

\section{Materials and methods}

\section{Cell strains and culture conditions}

The cell strains used for the experiments are given in Table 1. The primary fibroblasts are cultured in Ham's F10 medium supplied with $7.5 \%$ fetal (FCS) and 7.5\% newborn calf serum (NCS), penicillin 100 I.E. $/ \mathrm{ml}$ and streptomycin 100 $\mu \mathrm{g} / \mathrm{ml}$.

\section{Purification of PRE}

The photoreactivating enzyme is purified from Saccharomyces cerevisiae strain Ya 1-27a(pA8-3). Ya 1-27a(pA8-3) is strain Ya 1-27a (MATa rad1-1 phr1-1 ade1-1 his3 leu2) transformed with the recombinant plasmid pA8-3 (containing the cloned yeast PHR-1 gene) (Yasui and Chevalier, 1983). On the basis of restriction enzyme mapping, this enzyme may be identical to the yeast PRE as described by Schild et al. (1984). Purification of yeast PRE has been described previously (Zwetsloot et al., 1985). The microinjected enzyme is highly active in the in vitro Haemophilus influenzae transformation assay (Rupert et al., 1958; Zwetsloot et al., 1985; for experimental details see Piessens and Eker, 1975).
TABLE 1

CELL STRAINS USED

\begin{tabular}{|c|c|c|}
\hline $\begin{array}{l}\text { Cell } \\
\text { strains }\end{array}$ & $\begin{array}{l}\text { Classifi- } \\
\text { cation }\end{array}$ & References \\
\hline $\mathrm{C} 3 \mathrm{RO}$ & normal & - \\
\hline C5RO & normal & - \\
\hline XP8LO & $X P-A$ & de Weerd-Kastelein. 1976 \\
\hline XP6RO ${ }^{2}$ & $\mathrm{XP}-\mathrm{C}$ & W. Keyzer, personal communication \\
\hline $\mathrm{XP7RO} \mathrm{R}^{2}$ & $\mathrm{XP}-\mathrm{C}$ & W. Keyzer, personal communication \\
\hline XP21RO & XP-C & Bootsma, 1973 \\
\hline XP1TE & $\mathrm{XP}-\mathrm{C}$ & de Weerd-Kastelein, 1977 \\
\hline XP6BE & XP-D & Kraemer, 1975 \\
\hline XP1BR & XP-D & W. Keyzer, unpublished results \\
\hline XP2RO & $X P-E$ & de Weerd-Kastelein, 1974 \\
\hline XP126LO & XP-F & W. Keyzer, unpublished results \\
\hline XP42RO & $X P \cdot F$ & W. Keyzer, unpublished results \\
\hline XPCS2 & XP-H & Moshell, 1983 \\
\hline XP3MA & XP-I & Fischer, 1985 \\
\hline XP7TA & XP-Variant & Jaspers, 1981 \\
\hline XP37RO & XP.Variant & Jaspers, 1981 \\
\hline
\end{tabular}

1 All cell lines used are primary fibroblasts.

${ }^{2}$ XP6RO and XP7RO are sibs.

\section{Microinjection of PRE}

The procedure for microinjection has already been described (de Jonge et al., 1983; Zwetsloot et al., 1985). Prior to microinjection, fibroblasts were treated with inactivated Sendai virus to generate multinucleated cells (homopolykaryons) (de Weerd-Kastelein et al., 1972) and cultured for 3-5 days on $6 \times 8 \mathrm{~mm}$ pieces of a microscopic slide with a $2 \mathrm{~mm}$ grid. Only homopolykaryons are injected with PRE to facilitate the identification of the injected cells after UDS and autoradiography and to prevent confusion of early or late DNA replication in cells in S-phase with UDS (3 days after fusion cells do not enter S-phase). The microscope was provided with a yellow filter and the injection was carried out in semi-darkness to prevent premature photoreactivation. After injection (a procedure which usually takes less than $20 \mathrm{~min}$ ), the cells are UV-irradiated $\left(10 \mathrm{~J} / \mathrm{m}^{2}\right.$; Philips TUV 15-W lamp) and either illuminated with photoreactivating light (1 h, 4 Blacklite/Blue lamps F20/T12BLB (Sylvania) at a distance of $10 \mathrm{~cm}$ through a $6-\mathrm{mm}$ thick glass plate) or kept in the dark. During the illumination period the cells are 
TABLE 2

EFFECT OF MICROINJECTED YEAST PHOTOREACTIVATING ENZYME ON THE UV-INDUCED RESIDUAL UDS IN REPAIR-PROFICIENT (NORMAL) AND REPAIR-DEFICIENT (XP) HUMAN FIBROBLASTS

\begin{tabular}{|c|c|c|c|}
\hline $\begin{array}{l}\text { Cell } \\
\text { strain }\end{array}$ & $\begin{array}{l}\text { Excision- } \\
\text { repair } \\
\text { capacity }{ }^{2}\end{array}$ & $\begin{array}{l}\text { PR } \\
\text { illumi- } \\
\text { nation }^{3}\end{array}$ & $\begin{array}{l}\% \text { UDS } \pm \text { SEM } \\
\text { inj. } / \text { noninj. } \\
\times 100 \%^{4}\end{array}$ \\
\hline C5RO *(control) & $100 \pm 5$ & - & $\begin{array}{l}86 \pm 7 \\
23 \pm 2\end{array}$ \\
\hline C3RO(control) & $100 \pm 6$ & $\begin{array}{l}- \\
+\end{array}$ & $\begin{array}{r}100 \pm 6 \\
23 \pm 2\end{array}$ \\
\hline XP8LO $*(X P-A)^{5}$ & $49 \pm 4$ & + & $\begin{array}{l}104 \pm 9 \\
105 \pm 11\end{array}$ \\
\hline XP6RO(XP-C) & $17 \pm 1$ & $\overline{+}$ & $\begin{array}{r}106 \pm 9 \\
54 \pm 4\end{array}$ \\
\hline XP7RO(XP-C) & $18 \pm 1$ & - & $\begin{array}{l}\text { n.d. } \\
51 \pm 5\end{array}$ \\
\hline$X P 21 R O(X P-C)$ & $18 \pm 1$ & + & $\begin{array}{l}98 \pm 7 \\
53 \pm 4\end{array}$ \\
\hline XP1TE(XP-C) & $16 \pm 1$ & + & $\begin{array}{l}\text { n.d. } \\
64 \pm 5\end{array}$ \\
\hline XP6BE * (XP-D) & $25 \pm 2$ & $\overline{+}$ & $\begin{array}{l}95 \pm 6 \\
94 \pm 7\end{array}$ \\
\hline XP1BR(XP-D) & $23 \pm 2$ & $\begin{array}{l}- \\
+\end{array}$ & $\begin{array}{l}\text { n.d. } \\
102 \pm 6\end{array}$ \\
\hline XP2RO(XP-E) & $44 \pm 4$ & $\overline{-}$ & $\begin{array}{l}103 \pm 9 \\
106 \pm 8\end{array}$ \\
\hline XP126LO * XP-F) & $11 \pm 1$ & $\overline{+}$ & $\begin{array}{r}104 \pm 10 \\
81 \pm 8\end{array}$ \\
\hline XP42RO(XP-F) & $21 \pm 1$ & $\overline{+}$ & $\begin{array}{r}103 \pm 8 \\
82 \pm 8\end{array}$ \\
\hline $\mathrm{XPCS} 2 *(\mathrm{XP}-\mathrm{H})$ & $50 \pm 3$ & $\overline{+}$ & $\begin{array}{l}113 \pm 9 \\
100 \pm 8\end{array}$ \\
\hline XP3MA(XP-I) & $16 \pm 1$ & - & $\begin{array}{r}105 \pm 9 \\
38 \pm 5\end{array}$ \\
\hline XP7TA(XP-Variant) & $100 \pm 5$ & $\overline{+}$ & $\begin{array}{l}95 \pm 5 \\
18 \pm 1\end{array}$ \\
\hline XP37RO(XP-Variant) & $100 \pm 5$ & + & $\begin{array}{l}\text { n.d. } \\
27 \pm 5\end{array}$ \\
\hline
\end{tabular}

n.d., not determined.

(1) Cell strains marked with an asterisk are tested more than once. (2) In every experiment the C5RO strain was injected with purified yeast-PRE as a control. The excision-repair capacity of the XP-strains is calculated as a percentage of the UDS of the non-injected C5RO-cells (about 200-250 grains are counted above the nuclei of wild-type cells). (3) In this column is indicated whether the cells are PR-illuminated or not. (4) In each case the average number of grains per nucleus is determined by counting $>50$ nuclei. (5) XP8LO has a high residual UDS in contrast to most other XP-A strains.

kept in culture medium under constant $\mathrm{CO}_{2}$ flush, at a temperature of $34-38^{\circ} \mathrm{C}$. UDS was performed in F10 medium supplemented with $10 \%$ dialyzed

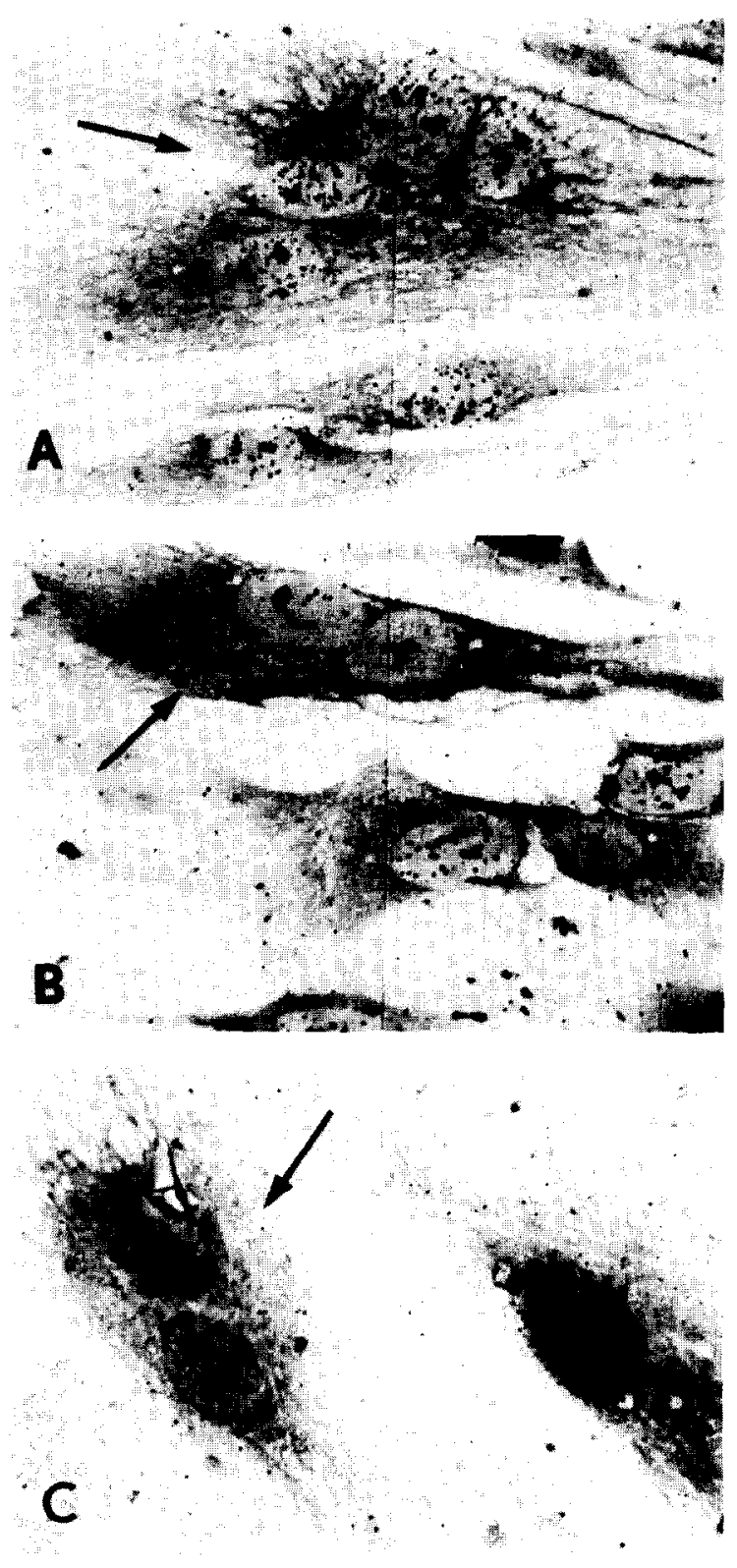

Fig. 1. Microinjection of yeast PRE into XP-homopolykaryons belonging to 3 different XP-strains followed by UV-irradiation $\left(10 \mathrm{~J} / \mathrm{m}^{2}\right)$ and PR-illumination $(1 \mathrm{~h})$. The injected cells are indicated with an arrow. (A) XPCS2(XP-H), no reduction observed. (B) XP21RO(XP-C), reduction of UDS in the injected cells is about $50 \%$ compared to the non-injected cells. $(C)$ XP7TA(XP-Variant), reduction of UDS in the injected cells is about $80 \%$.

FCS and with $10 \mu \mathrm{Ci} / \mathrm{ml}\left[{ }^{3} \mathrm{H}\right]$ thymidine $\left({ }^{3} \mathrm{H}-\mathrm{TdR}\right.$, spec. act, $46 \mathrm{Ci} / \mathrm{mmole})$ as described by Zelle and Bootsma (1980) for a period of $2 \mathrm{~h}$. Dialysis of the 
serum increases the sensitivity of the UDS assay (de Jonge et al., 1985).

\section{Results}

To investigate the effect of yeast PRE on the residual UDS in XP-cells the enzyme was injected into fibroblasts belonging to several XP-groups with a relatively high residual UDS (more than $10 \%$ of the UDS of wild-type cells). After injection, the cells were irradiated with a UV-dose of $10 \mathrm{~J} / \mathrm{m}^{2}$ and either illuminated for $1 \mathrm{~h}$ with photoreactivating light or incubated in the dark. The effect of this treatment on the UDS of normal human (C3RO and C5RO) and various XP-cells is shown in Table 2.

UDS in C3RO and C5RO cells is significantly reduced, whereas injection of PRE into cells belonging to the excision deficient XP-complementation groups A (XP8LO), D (XP6BE and XP1BR), $E(X P 2 R O)$ and $H(X P C S 2)$ did not show an effect on the UDS level following PR-illumination (Table 2, Fig. 1a).

With 4 cell strains belonging to complementation group XP-C and 1 to XP-I, a clear reduction in UDS was observed (Fig. 1B, Table 2). The UDS level of XP-C and XP-I strains (40-50 grains/ nucleus) is about $17 \%$ of the wild-type level. Following microinjection with PRE and PR-illumination, the residual UDS in those strains decreased to about $50 \%$ of UDS in non-injected cells; this is $8-9 \%$ of the wild-type level. Apparently the reduction of UV-induced UDS by injection of yeast $P R E$ in cells belonging to group $C$ is a constant feature of this complementation group. Since only one strain of complementation group I is available, it was impossible to investigate whether the observed effect is consistent in this group as well.

The residual UDS in two XP-F cell strains tested (XP126LO and XP42RO) is about 10-20\% (30-45 grains / nucleus) of the wild-type level during the first hours after UV-irradiation (Table 2). Microinjection with PRE followed by PR-illumination causes a slight but significant reduction of UDS in the injected cells during this period (reduction to about $82 \%$ compared to non-injected cells).

PRE injected into two XP-variant strains (XP7TA and XP37RO) exerted a similar effect as duced UDS to approximately $20 \%$ (Table 2, Fig. 1C).

\section{Discussion}

Microinjection of purified PRE from yeast into the cytoplasm of fused fibroblasts followed by PR-illumination reduces UDS in excision-repairproficient (wild-type and XP-variant) cells and in the excision-repair-deficient lines belonging to groups $\mathrm{C}, \mathrm{F}$ and $\mathrm{I}$. The observed reduction in UDS was dependent on PR-illumination. No reduction of UV-induced residual UDS was noticed in cell strains from four other excision-repair-deficient XP-groups (A, D, E and H).

In a previous paper (Zwetsloot et al., 1985) we demonstrated that the PRE-induced reduction in UDS in normal cells is caused by monomerization of pyrimidine dimers in the chromatin of mammalian cells. Therefore the most plausible interpretation for the UDS reduction found in XP-C, F and $I$ is that part of the residual UDS in these groups is due to the endogenous excision repair of dimers and that these dimers are accessible for and can be monomerized by the injected PRE.

The residual UDS in XP-C is about $17 \%$ of the wild-type UDS-level and even this low residual UDS is reduced (to about 50\%) after microinjection with purified PRE. Since this result is found in all $4 \mathrm{XP}-\mathrm{C}$ lines tested it strongly suggests that the accessibility of the dimers for PRE is a general property of this complementation group. Mansbridge and Hanawalt (1983) demonstrated that repair in XP-C fibroblasts takes place in localized domains. These domains are situated near the attachment site of the DNA loops to the nuclear matrix (Mullenders et al., 1984) and repair in those domains appears to be normal. In view of their observations our data concerning XP-C cell strains can be explained in two ways. Firstly, PRE operates at the same place as the endogenous $\mathrm{XP}-\mathrm{C}$ excision-repair enzymes, i.e. at the matrix, where it competes with these enzymes for removal of dimers. Secondly, PRE monomerizes dimers throughout the entire XP-C nucleus thus removing dimers probably in the same manner as in wild-type cells. The present data do not discriminate between the two possibilities. 
The number of grains above the nuclei of PRE treated XP-I cells is reduced by $60 \%$, a result comparable with the PRE effect in XP-C. These results and the fact that XP-I resembles XP-C in several biochemical and clinical features (Fischer et al., 1985) make it interesting to investigate if the XP-I group also shows domain-limited repair.

Excision repair in XP-F apparently takes place at a much lower rate than in normal excision-repair-proficient fibroblasts (Zelle and Lohman, 1979; Hayakawa et al., 1981). When the effect of PRE on the residual UDS of XP-F fibroblasts was determined following the standard procedure a minor reduction (15-20\%) was observed in two XP-F strains (XP126LO and XP42RO). The low but significant reduction in UDS measured for XP-F indicates that only a small fraction of dimers that is repaired by the endogenous excision repair during the first few hours after UV-irradiation is accessible for or recognized by PRE. Measurement of UDS during a period of $24 \mathrm{~h}$ after microinjection of PRE and PR-illumination revealed no further decrease in UDS level in these cells (data not shown).

The residual UDS after injection with PRE and PR-illumination in the XP-groups discussed so far may in all cases be due to non-dimer damage, dimers modified by the endogenous excision repair or dimer lesions inaccessible for PRE.

XP-cells belonging to groups A (XP8LO), D (XP6BE and XP1BR), E (XP2RO) and H (XPCS2) form a second category. During the assay period, UV-induced UDS in these groups is not reduced by the injected yeast PRE. Mortelmans et al. (1976) and Fujiwara and Kano (1983) have demonstrated that several XP-groups (XP-A, C, D and G have been tested) do have the capacity to perform the incision step next to dimers in purified DNA in an in vitro assay. They postulate that in these XPgroups, dimers in the chromatin are inaccessible for the excision-repair enzymes. Considering the high residual level of UDS in the cell strains tested we assume that at least part of the residual UDS in these XP-cells is due to the excision repair of dimers. The lack of UDS reduction in these cells following PRE injection and PR-illumination can be explained in several ways. One possibility is that PRE is unable to reach the UV-induced di- mers that can be repaired by the endogenous enzymes. This inaccessibility of dimers for PRE may be due to an altered chromatin structure or to a defective excision-repair protein which blocks the dimers for PRE. Inaccessibility of DNA damage in XP-cells for exogenous proteins was not observed by Tanaka et al. (1975) and de Jonge et al. (1985). They demonstrated that two other exogenous enzymes T4-endonuclease V (16000 dalton, Nakabeppu and Sekiguchi, 1981) and Micrococcus luteus endonuclease (18000 dalton, Grafstrom et al., 1982) are able to reach dimers in all excision-deficient XP-complementation groups. PRE from yeast is larger (60000 dalton, Yasui, personal communication; Iwatsuki et al., 1980) than these two prokaryotic enzymes; moreover its binding properties to DNA may differ from those of the prokaryotic endonucleases. Another possibility is that the endogenous repair enzymes modify the dimer sites thus providing lesions that are not recognized by PRE.

The excision-repair capacity of the XP-variant strains is normal (Lehmann et al., 1975). We assume that the observed reduction of UV-induced UDS found in the XP-variant fibroblasts is essentially the same as the reduction observed in normal strains.

Several reports by Sutherland et al. (1975a,b) describe experiments which demonstrate endogenous PRE-activity in several XP-complementation groups. They claim the detection of relatively high levels of PRE-activity in XP-A and XP-E (36\% and $50 \%$ of wild-type level respectively) and low levels in XP-B (0\%), XP-C (16\%), XP-D (8\%) and $X P$-variant $(4 \%)$. These levels of PRE activity in XP-cells do not correspond to the positive and negative responses of XP-cells after injection of exogenous PRE. Nor did we find any evidence for endogenous PRE activity in human fibroblasts.

In general, the data presented in this paper show that XP-cells belonging to different complementation groups react differently to an exogenously inserted enzyme. Experiments are in progress to investigate the long-term effect of the photoreversal of dimers on cellular parameters such as survival and mutagenesis by introducing the cloned yeast PHR-gene into the various XP-cells. 


\section{Acknowledgements}

The authors wish to thank A. Yasui and N.G.J. Jaspers for helpful discussion. We are grateful to T. van Os who did the photographic work. This work was supported by The Foundation for Medical Research FUNGO, contract No. 13-23-35, and the Commission of the European Community, contract No. BIO-E-404-NL.

\section{References}

Bootsma, D., W. Keyzer, W.J. Kleyer, E.A. de Weerd-Kastelein, J. de Wit, P. Meera Khan, H. van Someren and A. Westerveld (1973) Mammalian cell culture studies, Genetics (Suppl. 73), 167-179.

Cleaver, J.E. (1968) Defective repair replication of DNA in xeroderma pigmentosum, Nature (London), 218, 652-656.

Cook, J.S. (1970) Photoreactivation in animal cells, in: A.C. Giese (Ed.), Photophysiology, Vol. 5, Academic Press, New York, pp. 191-233.

de Jonge, A.J.R., W. Vermeulen, B. Klein and J.H.J. Hoeymakers (1983) Microinjection of human cell extracts corrects xeroderma pigmentosum defect, EMBO J., 2, 637-641.

de Jonge, A.J.R., W. Vermeulen, W. Keyzer, J.H.J. Hoeymakers and D. Bootsma (1985) Microinjection of Micrococcus luteus UV-endonuclease restores UV-induced unscheduled DNA synthesis in cells of 9 xeroderma pigmentosum complementation groups, Mutation Res., 150, 99-105.

de Weerd-Kastelein, E.A., W. Keyzer and D. Bootsma (1972) Genetic heterogeneity of xeroderma pigmentosum demonstrated by somatic cell hybridization, Nature New Biol. (London), 238, 80-83.

de Weerd-Kastelein, E.A., W. Keyzer and D. Bootsma (1974) A third complementation group in xeroderma pigmentosum, Mutation Res., 22, 87-91.

de Weerd-Kastelein, E.A., W. Keyzer, M. Sabour, J.M. Parrington and D. Bootsma (1976) A xeroderma pigmentosum patient having a high residual activity of unscheduled DNA synthesis after UV is assigned to complementation group $\mathrm{A}$, Mutation Res., 37, 307-312.

de Weerd-Kastelein, E.A., W. Keyzer, G. Rainaldi and D. Bootsma (1977) Induction of sister chromatid exchanges in xeroderma pigmentosum cells after exposure to ultraviolet light, Mutation Res., 45, 253-261.

Eker, A.P.M. (1983) Photorepair processes, in: G. Montagnoli and B.F. Erlanger (Eds.), Molecular Models of Photoresponsiveness, Plenum, New York, pp. 109-132.

Fischer, E., W. Keyzer, H.W. Thielmann, O. Popanda, E. Bohnert, L. Edler, E.G. Jung and D. Bootsma (1985) A ninth complementation group in xeroderma pigmentosum, XP-I, Mutation Res., 145, 217-225.

Fujiwara, Y., and Y. Kano (1983) Characteristics of thymine dimer excision from xeroderma pigmentosum chromatin, in: E.C. Friedberg and B.A. Bridges (Eds.), Cellular Responses to DNA-Damage, Liss, New York, pp. 215-225.
Grafstrom, R.H., L. Park and L. Grossman (1982) Enzymatic repair of pyrimidine dimer-containing DNA, J. Biol. Chem., $257,13465-13474$.

Hayakawa, H., K. Ishizaki, M. Inoue, T. Yagi, M. Sekiguchi and $H$. Takebe (1981) Repair of ultraviolet radiation damage in xeroderma pigmentosum cells belonging to complementation group F, Mutation Res., 80, 381-388.

Iwatsuki, N., C.O. Joe and H. Werbin (1980) Evidence that deoxyribonucleic acid photolyase from Baker's yeast is a flavoprotein, Biochemistry, 19, 1172-1176.

Jaspers, N.G.J., G. Jansen-van de Kuillen and D. Bootsma (1981) Complementation analysis of xeroderma pigmentosum variants, Exp. Cell Res., 136, 81-90.

Kraemer, K.H. (1983) Heritable diseases with increased sensitivity to cellular injury, in: T.B. Fitzpatrick, A.Z. Eisen, K. Wolff, I.M. Freedberg and K.F. Austen (Eds.), Update: Dermatology in General Medicine, McGraw-Hill, New York, pp. 113-141.

Kraemer, K.H., E.A. de Weerd-Kastelein, J.H. Robbins, W. Keyzer, S.F. Barrett, R.A. Petinga and D. Bootsma (1975) Five complementation groups in xeroderma pigmentosum, Mutation Res., 33, 327-340.

Lehmann, A.R., and P. Karran (1981) DNA repair, Int. Rev. Cytol., 72, 101-146.

Lehmann, A.R., S. Kirk-Bell, C.F. Arlett, M.C. Paterson, P.H.M. Lohman, E.A. de Weerd-Kastelein and D. Bootsma (1975) Xeroderma pigmentosum cells with a normal level of excision repair have a defect in DNA synthesis after UVirradiation, Proc. Natl. Acad. Sci. (U.S.A.), 72, 219-223.

Mansbridge, J.N, and P.C. Hanawalt (1983) Domain-limited repair of DNA in ultraviolet irradiated fibroblasts from xeroderma pigmentosum complementation group $\mathrm{C}$ in: E.C. Friedberg and B.A. Bridges (Eds.), Cellular Resposes to DNA Damage, Liss, New York, pp. 195-207.

Mortelmans, K., E.C. Friedberg, H. Slor, G. Thomas and J.E. Cleaver (1976) Defective thymidine dimer excision by cell free extracts of xeroderma pigmentosum cells, Proc. Natl. Acad. Sci. (U.S.A.), 73, 2757-2761.

Mortelmans, K., J.E. Cleaver, E.C. Friedberg, M.C. Paterson, B.P. Smith and G.H. Thomas (1977) Photoreactivation of thymine dimers in UV-irradiated human cells: unique dependence on culture conditions, Mutation Res., 44, 433-446.

Moshell, A.N., M.B. Ganges, M.A. Lutzner, H.G. Coon, S.F. Barrett, J.-M. Dupuy and J.H. Robbins (1983) A new patient with both xeroderma pigmentosum and Cockayne syndrome establishes the new complementation group $H$, in: E.C. Friedberg and B.A. Bridges (Eds.), Cellular Responses to DNA Damage, Liss, New York, pp. 209-213.

Mullenders, L.H.F., A.A. Van Kesteren, G.J.M. Bussman, A.A. van Zeeland and A.T. Natarajan (1984) Preferential repair of nuclear matrix associated DNA in xeroderma pigmentosum group C, Mutation Res., 141, 75-82.

Nakabeppu, Y., and M. Sekiguchi (1981) Physical association of pyrimidine dimer DNA glycosylase and apurinic/ apyrimidinic DNA endonuclease essential for repair of ultraviolet-damaged DNA, Proc. Natl. Acad. Sci. (U.S.A.), $78,2742-2746$.

Piessens, J.P., and A.P.M. Eker (1975) Photoreactivation of template activity of UV-irradiated DNA in an RNA-poly- 
merase system, A rapid assay for photoreactivating system, FEBS Lett., 50, 125-129.

Rupert, C.S. (1975) Enzymatic photoreactivation: Overview, in: P.C. Hanawalt and R.B. Setlow (Eds.), Molecular Mechanisms for Repair of DNA, Part A, Plenum, New York, pp. 73-87.

Rupert, C.S., S.H. Goodgal and R.M. Herriott (1958) Photoreactivation in vitro of ultraviolet inactivated Haemophilus influenzae transforming factor, J. Gen. Physiol., 41, 451-456.

Schild, D., J. Johnston, C. Chang and R.K. Mortimer (1984) Cloning and mapping of Saccharomyces cerevisiae photoreactivation gene PHRI, Mol. Cell. Biol., 4, 1864-1870.

Setlow, J.K. (1972) Photorepair of biological systems, in: K. Gallo and L. Santamaria (Eds.), Research Progress in Organic, Biological and Medicinal Chemistry, Vol. 3, North-Holland, Amsterdam, pp. 335-355.

Sutherland, B.M. (1974a) Photoreactivating enzyme from human leukocytes, Nature (London), 248, 109-112.

Sutherland, B.M., P. Runge and J.C. Sutherland (1974b) DNA photoreactivating enzyme from placental mammals, origin and characteristics, Biochemistry, 13, 4710-4715.

Sutherland, B.M., M. Rice and E.K. Wagner (1975a) Xeroderma pigmentosum cells contain low levels of photoreactivating enzyme, Proc. Natl. Acad. Sci. (U.S.A.), 72, 103-107.

Sutherland, B.M., and O. Oliver (1975b) Low levels of photore- activating enzyme in xeroderma pigmentosum variants. $\mathrm{Na}$ ture (London), 257, 132-134.

Sutherland, B.M., and A. Castellani (1982) Photoreactivating enzyme induction in human lymphocytes, Photochem. Photobiol., 35, 275-277.

Tanaka, K., M. Sekiguchi and Y. Okada (1975) Restoration of ultraviolet induced unscheduled DNA synthesis of xeroderma pigmentosum cells by the concomitant treatment with bacteriophage T4 endonuclease $V$ and HVJ (Sendai virus), Proc. Natl. Acad. Sci. (U.S.A.), 72, 4071-4075.

Yasui, A., and M.R. Chevalier (1983) Cloning of photoreactivation repair gene and excision repair gene of the yeast Sächaromyces cerevisiae, Curr. Genet., 7, 191-194.

Zelle, B., and D. Bootsma (1980) Repair of DNA damage after exposure to 4-nitroquinoline-1-oxide in heterokaryons derived from xeroderma pigmentosum cells, Mutation Res., 70, 373-381.

Zelle, B., and P.H.M. Lohman (1979) Repair of UV-endonuclease-susceptible sites in the 7 complementation groups of xeroderma pigmentosum A through G, Mutation Res., 62, 363-368.

Zwetsloot, J.C.M., W. Vermeulen, J.H.J. Hoeymakers, A. Yasui, A.P.M. Eker and D. Bootsma (1985) Microinjected photoreactivating enzymes from Anacystis and Saccharomyces monomerize dimers in chromatin of human cells, Mutation Res., 146, 71-77. 